\title{
Pedestrian Environments and Transit Ridership
}

\author{
Sherry Ryan, Ph.D., San Diego State University \\ Lawrence F. Frank, Ph.D., AICP, ASLA, University of British Columbia
}

\begin{abstract}
This paper explores how the quality of the pedestrian environment around transit stops relates with transit ridership. The primary hypothesis tested is that transit tripmaking is higher in urban environments that are more conducive to non-motorized travel, given that bus transit systems are most frequently accessed via walking or biking. A secondary goal is to contribute to an improved understanding of the measurement of the built environment in geographic information systems (GIS). A composite measure of walkability-incorporating land use mix, density and street patterns-was developed for all transit stops in San Diego's Metropolitan Transit Systems service area and used as a measure of the built environment. Findings indicate a small but significant, positive relationship between the walkability of the built environment and transit ridership.
\end{abstract}

\section{Introduction}

This research assesses the relationship between transit ridership and the quality of the pedestrian environment near bus transit stops. Academic and professional planners have theorized about the importance of the built environment in shaping an individual's travel behavior (Ewing and Cervero 2001; Handy 1996; Frank, Engelke, and Schmid 2003; Krizek 2003). The current research tests the nature of this relationship using bus ridership and built-environment data from the San Diego region. The primary hypothesis of this research is that transit trip-making is 
higher in urban environments that are more conducive to non-motorized travel, given that bus transit systems are most frequently accessed via walking or biking. A secondary goal is to contribute to an improved understanding of the measurement of the built environment in geographic information systems (GIS).

\section{Literature Review}

Several important strands of literature examine the relationship between various human behaviors and the built environment. Previous studies have assessed associations between the built environment and a range of human behaviors, including travel behavior, community capacity-building behaviors, criminal behavior, and health-promoting behaviors. Highlights of this research are summarized in the following paragraphs, with a focus on delineating how researchers from different disciplines approach measurement of the built environment, especially in regard to methods and spatial units of analysis.

\section{Travel Behavior}

Much of the relevant travel behavior literature focuses on improving our understanding of how the built environment influences an individual's travel mode choice, specifically the decision to drive versus walk, bike, or use public transit (Zhang 2004). New urbanists and smart growth advocates suggest that changes in the built environment could lead to more frequent decisions to use non-motorized modes of travel (Duany, Plater-Zyberk, and Speck 2000; Calthorpe 1993; Frank et al. 2004). Aspects of the built environment thought to influence travel mode choice include population or residential density, land use mix, and characteristics of the transportation system (Cervero and Kockelman 1997).

The travel behavior literature employs a range of built-environment measurements where the unit of analysis varies from the street block at the smallest level up to the metropolitan area in its entirety. Recent research by Boarnet et al. (2005), for example, employs an environmental assessment survey where field observers walked from street block to street block within a particular study area noting specific attributes of each block, such as sidewalk widths, presence of trash, and presence of tree canopy. Krizek (2003), Song and Rodriquez (2005), and Frank et al. (2005) employ an artificial grid composed of small cells (ranging from $150 \mathrm{~m}$ $x 150 \mathrm{~m}$ to $1 \mathrm{~km} \times 1 \mathrm{~km}$ ) laid out across an urban area and then utilized to calculate measures of the built environment. Frank et al. (2004; 2006) measured the built environment within a one-kilometer road network distance of where people live. 
Perhaps most commonly, researchers define the built environment in terms of readily available planning zonal systems such as census tracts or traffic analysis zones (Zhang 2004). The most aggregated approach to assessing the built environment and travel behavior is seen in studies such as Bento et al. (2005), where metropolitan-wide data are compared for a series of urban areas across a nation or a series of counties across a state (Ewing, Pendall, and Chen 2003). Newman and Kenworthy (1989) also conducted a seminal study documenting relationships between travel behavior and urban form at the metropolitan-wide level. Table 1 summarizes some of the recent research methods and findings related to travel behavior and the built environment.

\section{Table 1. Overview of Representative Travel Behavior and Built Environment Research}

\begin{tabular}{|c|c|c|c|c|}
\hline Researcher & $\begin{array}{l}\text { Level of Data } \\
\text { Aggregation }\end{array}$ & $\begin{array}{c}\text { Travel Behavior } \\
\text { Measures }\end{array}$ & Built Environment Measures & Relationship \\
\hline $\begin{array}{l}\text { Boarnet et al. } \\
\text { (2005) }\end{array}$ & Street block & School walk trip & $\begin{array}{l}\text { Presence of sidewalk } \\
\text { Presence of traffic signal }\end{array}$ & 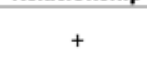 \\
\hline \multirow[t]{2}{*}{ Krizek (2003) } & \multirow[t]{2}{*}{$150 \mathrm{~m}$ grid cell } & VMT & \multirow{2}{*}{$\begin{array}{l}\text { Neighborhood accessibility } \\
\text { (composite of residential density, } \\
\text { number of retail employees, and } \\
\text { street block size) }\end{array}$} & - \\
\hline & & Number of tours & & + \\
\hline $\begin{array}{l}\text { Frank et al. } \\
\text { (2004 and } \\
2005)\end{array}$ & $\begin{array}{l}1 \mathrm{~km} \text { road } \\
\text { network buffer }\end{array}$ & $\begin{array}{l}\text { Walk distance, car } \\
\text { time, moderate } \\
\text { intensity physical } \\
\text { activity }\end{array}$ & $\begin{array}{l}\text { Walkability index (composite of } \\
\text { land use mix, residential density, } \\
\text { street network density, and retail } \\
\text { FAR) }\end{array}$ & + \\
\hline Zhang (2004) & $\begin{array}{l}\text { Traffic analysis } \\
\text { zone (TAZ) }\end{array}$ & $\begin{array}{l}\text { Non driving work and } \\
\text { non-work trips }\end{array}$ & $\begin{array}{l}\text { Population density, employment } \\
\text { density, land use balance, street } \\
\text { connectivity }\end{array}$ & + \\
\hline $\begin{array}{l}\text { Bento et al. } \\
(2005)\end{array}$ & $\begin{array}{l}\text { Metropolitan } \\
\text { Statistical Area }\end{array}$ & $\begin{array}{l}\text { Number of bus, rail, } \\
\text { and non-motorized } \\
\text { trips }\end{array}$ & $\begin{array}{l}\text { Population density, employment } \\
\text { density, jobs-housing balance, } \\
\text { network density }\end{array}$ & + \\
\hline $\begin{array}{l}\text { Newman and } \\
\text { Kenworthy } \\
\text { (1989) }\end{array}$ & $\begin{array}{l}\text { Metropolitan } \\
\text { Statistical Area }\end{array}$ & Gasoline consumption & $\begin{array}{l}\text { Population density, employment } \\
\text { density }\end{array}$ & - \\
\hline
\end{tabular}

\section{Social Capital-Building Behaviors}

Sociologists, urban planners, political scientists, and social ecologists examine how the built environment affects the degree to which individuals engage with other community members, thereby engendering strong social networks and community attachment. New urbanists claim the street environment is a crucible for effective civic engagement and that poor-quality street environments hinder a range of neighboring and trust-building activities. New urbanists point to weakening civic engagement in the U.S. as stemming from declining street environment quality: community members literally have no common ground and no place to 
effectively engage with neighbors. Robert Putnam identified the decline of social capital in the U.S. (2000), while earlier, Jane Jacobs (1961) drew a more direct connection between social capital and the built environment with her maxim that more "eyes on the street" translates into less crime and other societal benefits. More recent researchers attempt to examine specific connections between the built environment and social capital. Demerath and Levinger (2003), for example, characterize "being on foot" as a uniquely rich opportunity for sensory stimulation and social interaction, both of which help the individual to find meaning in his world. Leyden (2003) shows that people living in "walkable" neighborhoods (defined as living in close proximity to community services, retail, and work sites) are more likely to know their neighbors, to participate politically, to trust others, and to be involved socially. Schaeffer and Schlar (1981) portray the critical role of transportation accessibility in defining divisions in social class and status.

\section{Criminal Behaviors}

The criminal justice literature examines the importance of environmental characteristics in deterring or enhancing opportunities for committing crimes against people and their property. Oscar Newman's research defines several key environmental characteristics, such as defensible space, territoriality, and natural surveillance-with the potential for deterring criminal behaviors (Newman 1972). Loukaitou-Sideris (1995) examines environmental characteristics of crime hot spots at bus transit stops and finds that lack of visibility from surrounding stores, vacant lots, dilapidated buildings, easy escape routes, and low levels of pedestrian activity near these bus stops are associated with higher rates of criminal behavior.

\section{Health Promoting Behaviors}

Health implications of the built environment are receiving increasing attention in the public health and city planning literatures, as witnessed by the recent special issues of academic journals such as the Journal of the American Planning Association's Winter 2006 issue and the Journal of Physical Activity and Health's January 2006 issue. The revival of collaborative efforts between public health and city planning was initiated by public health researchers peering into the work of city planners in an effort to understand those factors that shape the physical structure of cities, and how the physical structure of cities shapes our willingness to be on the street as a pedestrian or biker (Sallis et al. 2004; Saelens et al. 2003). Public health researchers initiated this path of investigation after years of research showing that education and other types of interventions help certain populations lead more actives lives, but this activity is difficult to sustain (Livizzo-Mourey and 
McGinnis 2003). Public health researchers are now rightfully wondering about the magnitude of the barrier to physical activity put in place by the mere structure of cities (King et al. 2002).

There is an increased urgency to develop more definitive measures of the built environment, especially given recent advances in GIS. To understand how the built environment shapes behavior (any of the aforementioned), it is necessary to employ rigorous measures of both the built environment and the behaviors in question. This conclusion was summarized by an important recent literature review of the built environment and physical activity (Transportation Research Board and Institute of Medicine 2005). To date, there are shortcomings in measuring those aspects of the built environment posited to influence travel behavior. An important goal of this paper is to apply recently-developed methods for measuring the built environment to the choice to ride public transportation.

\section{Methods}

\section{Study Area}

The San Diego region serves as the study area for this research, with a specific focus on the San Diego Metropolitan Transit System (MTS) bus service area. Total population for the San Diego region was approximately three million in 2005, with a median household income of $\$ 64,000$. Census 2000 data reveal approximately 67 percent of the total population is White and 33 percent is Non-White; only 8 percent of total households do not own a vehicle, and the average travel time to work is 26 minutes. Seventy-four percent of workers over 16 years of age drive alone to work, while 26 percent either carpool, use transit, walk, or bike to work.

Figure 1 displays the San Diego region along with the MTS service area. The MTS service area traverses approximately 2,658 square miles and 11 local jurisdictions. MTS provides bus transit service via 90 fixed-route bus lines with service frequencies ranging from 7 to 120 minutes, constituting considerable variation in the level of service.

\section{Data}

This section summarizes data sources and their development in GIS. Environmental Systems Research Institute's (ESRI) ArcView 9.1 was used to develop builtenvironment measures following a similar methodology as Frank et al. (2006) for the Neighborhood Quality of Life Study. As mentioned in the literature review, previous researchers use varying spatial units of analysis for assessing the built 
Figure 1. San Diego Region and MTS Service Area

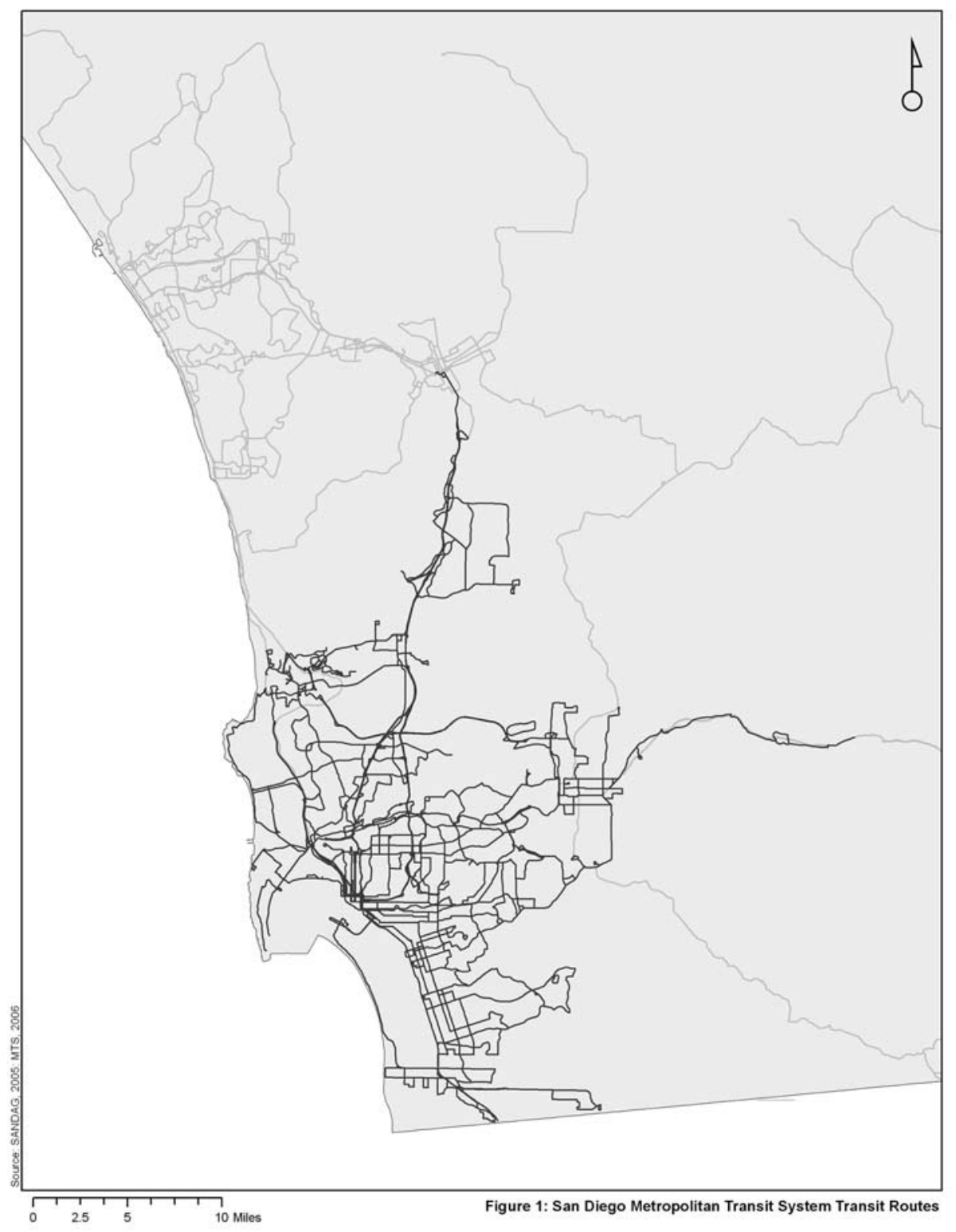


environment. In this study, a half-mile street network buffer was generated for each transit stop in the MTS service area and used as the unit of analysis. Each of the built environment and socio-economic characteristics is calculated for the area within a half-mile of the transit stop along the street network.

Four groups of data are utilized for model development in this research: bus ridership, transit level of service, built environment, and socio-economic. Table 2 displays each of the data groups, specific variables generated in GIS, a description of the variable, and the data source and date.

\section{Table 2. Data Types and Sources}

\begin{tabular}{|c|c|c|c|}
\hline Data Group & Variable & Description & Data Sources (Date) \\
\hline $\begin{array}{l}\text { Bus Ridership } \\
\text { (dependent } \\
\text { variable) }\end{array}$ & $\begin{array}{l}\text { Total daily bus } \\
\text { boardings and } \\
\text { alightings }\end{array}$ & $\begin{array}{l}\text { Daily number of passengers getting on } \\
\text { and off buses at any particular bus stop }\end{array}$ & $\begin{array}{l}\text { SANDAG' Transit Passenger } \\
\text { Counting Program (2002) }\end{array}$ \\
\hline $\begin{array}{l}\text { Transit Level of } \\
\text { Service } \\
\text { (independent } \\
\text { variable) }\end{array}$ & Level of Service & $\begin{array}{l}\text { Numbers of bus routes serving a bus stop } \\
\text { divided by the mean wait time of all } \\
\text { route serving the bus stop }\end{array}$ & MTS Service Schedule (2002) \\
\hline \multirow{4}{*}{$\begin{array}{l}\text { Built } \\
\text { Environment } \\
\text { (independent } \\
\text { variables) }\end{array}$} & $\begin{array}{l}\text { Residential } \\
\text { density }\end{array}$ & $\begin{array}{l}\text { Number of housing units per net } \\
\text { residential acre }\end{array}$ & $\begin{array}{l}\text { Housing Units - Census Bureau } \\
\text { data (2000); } \\
\text { Residential Acreage - SANDAG } \\
\text { Current Land Use Shapefile (2003) }\end{array}$ \\
\hline & $\begin{array}{l}\text { Retail floor area } \\
\text { ratio }\end{array}$ & $\begin{array}{l}\text { Square footage (SF) of retail buildings } \\
\text { divided by SF of retail parcels }\end{array}$ & $\begin{array}{l}\text { Building SF - DataQuick }{ }^{2} \text { (2002); } \\
\text { Parcel SF - SanGIS }{ }^{3} \text { (2002) }\end{array}$ \\
\hline & $\begin{array}{l}\text { Intersection } \\
\text { density }\end{array}$ & Number of intersections per acre & $\begin{array}{l}\text { Road Network Shapefile; SANDAG } \\
(2002)\end{array}$ \\
\hline & Land use mix & $\begin{array}{l}\text { Proportion of seven land use types } \\
\text { (commercial, industrial, institutional, } \\
\text { office, park and recreation, residential, } \\
\text { and vacant) within station area }\end{array}$ & $\begin{array}{l}\text { SANDAG Current Land Use } \\
\text { Shapefile (2003) }\end{array}$ \\
\hline \multirow{6}{*}{$\begin{array}{l}\text { Socio-Economic } \\
\text { (independent } \\
\text { variables) }\end{array}$} & Income & Median household income & Census Bureau (2000) \\
\hline & $\begin{array}{l}\text { No-vehicle } \\
\text { households }\end{array}$ & $\begin{array}{l}\text { Percent of total household without a } \\
\text { vehicle }\end{array}$ & Census Bureau (2000) \\
\hline & Percent female & Percent of total population that is female & Census Bureau (2000) \\
\hline & Percent Hispanic & $\begin{array}{l}\text { Percent of total population that is } \\
\text { Hispanic }\end{array}$ & Census Bureau (2000) \\
\hline & Percent White & Percent of total population that is White & Census Bureau (2000) \\
\hline & Percent Youth & $\begin{array}{l}\text { Percent of total population that is } 14 \\
\text { years or younger }\end{array}$ & Census Bureau (2000) \\
\hline
\end{tabular}

${ }^{1}$ San Diego Association of Governments

${ }^{2}$ DataQuick is a nationwide real estate data collection and information systems company.

${ }^{3}$ SanGIS was created in 1997 under a joint powers agreement between the City of San Diego and the County of San Diego to collect and maintain accurate geographic information systems data for the San Diego region.

Analyses conducted for this research required a considerable amount of data manipulation in GIS. The following paragraphs describe how each of the data types was calculated in GIS. 


\section{Bus Ridership Data}

Each MTS bus transit stop is depicted as a point in ArcView. SANDAG provided point attribute data consisting of total daily passenger "ons" and "offs" or boardings and alightings by bus route. Although the relationship between built-environment characteristics and the incidence of transit trip origins and destinations may differ, this research does not attempt to model transit trip origins and destinations separately, but rather uses the summation as an overall indication of the daily transit demand. Furthermore, since multiple routes can use a single transit stop, boardings and alightings were summed by transit stop across all routes. SANDAG counts passenger boardings and alightings and tracks on-time performance for each of the region's fixed transit routes as part of mandatory data reporting to the Federal Transit Administration. SANDAG's count program provides a count of boardings and alightings for every run of every bus in the system for a single day per year. Given this data collection limitation, there may be sampling error introduced in the dependent variable.

\section{Transit Level of Service}

A measure of transit level of service (LOS) was developed to capture the level of transit accessibility to multiple destinations as well as the amount of wait time between buses. Wait time was calculated as an average frequency of bus service at each transit stop using scheduled bus service. This resulted in a LOS measure for each bus stop in the database calculated as follows:

\section{Number of Bus Routes / Mean Wait Time}

Resulting calculations show that places with more routes and shorter wait times have the highest levels of service, whereas few routes and more wait time incur lower levels of service.

\section{Bus Transit Station Area}

The station area is defined as the area falling within a half-mile of the transit stop along the street network. The station areas are therefore irregular polygons due to irregularities in the street network and varying degrees of connectivity (Sallis et al. 2004). All built-environment and socio-economic variables are calculated for the half-mile station area in GIS. Given the proximity of some transit stops to each other, especially in dense urban environments, overlap between station area buffers can occur. All variables, however, are re-aggregated to the station buffer even when there is overlap between buffers. Using the station area polygon as the unit of analysis required overlaying census polygons and land use polygons on the 
station area buffer, intersecting and re-aggregating relevant data to the station area polygon.

A principal hypothesis of this research is that, after adjusting for socio-demographic and transit levels of service factors, transit ridership is higher for those stops located in half-mile station areas where the built environment is more conducive to walking.

\section{Built Environment Data}

As mentioned in the literature review, a significant body of evidence exists documenting how travel behavior varies based on three major characteristics of the built environment: land use density, land use mix, and street network patterns. This section describes the measurement of each built environment characteristic. Key methodologies for measuring the built environment in GIS are based on previous research conducted in Atlanta as part of the SMARTRAQ program (Frank et al. 2004) and in Seattle (Frank et al. 2006). However, these previous studies focused mainly on relationships between community walkability and physical activity, whereas the current study applies these methods to understanding transit ridership. In addition, a variation on the land use measure was required due to limitations in the San Diego parcel database. Specifically, the mixed-use measure employed in the current study is based on a land area and not floor-area calculation.

Land use density is a measure of the concentration of activity in a particular area. Higher concentrations of activity in any given area provide more opportunities within that area. It is thought that increased proximity to more land uses (even if it is the same type of land use) increases the likelihood that individuals will use non-motorized modes to access those land uses. Low-density land uses, where there is greater separation between any two land uses, encourages automobile travel to the extent that traveling longer distances deters human-powered travel such as walking and biking (Ewing and Cervero 2001). The same logic applies to station areas: higher land-use density near station areas places greater opportunities near the transit system, which should increase the propensity to use transit for accessing those opportunities, as well as other opportunities located along the system. In this research, land-use density near station areas is measured in terms of net residential density in the station area buffer, and average retail floor-area-ratio (FAR) in the station area buffer (Frank et al. 2006, 2005 and 2003). 
Land use mix is a measure of the number of different land uses within a given area. As with land-use density, the higher the number of land-use types, the greater the level of opportunity within a given area. Increased nearby opportunities implies increased opportunities within shorter distances, thereby heightening the potential for accessing these opportunities with a shorter trip, the kind that tend to be more amenable to non-motorized travel (Moudon and Lee 2005). In this research, land-use mix is measured in terms of entropy. The entropy equation was used by Frank et al. $(2006,2005)$ in recent research but originally applied by Cervero $(1988)$ to the study of travel behavior and further developed in additional analyses with Kockelman (Cervero and Kockelman 1997). The entropy equation can also be found in the environmental literature where it is referred to as the Shannon Index and is used to measure animal species diversity (Spellerberg and Fedor 2003). Land-use mix is measured using the following equation:

$$
\frac{-\sum\left[\mathrm{P}_{\mathrm{n}} * \ln \left(\mathrm{P}_{\mathrm{n}}\right)\right]}{\ln (\mathrm{N})}
$$

where

$$
\begin{aligned}
& \mathrm{N}=\text { the number of different land uses in the station buffer area } \\
& \mathrm{P}_{\mathrm{n}}=\text { the proportion of acres of the } \mathrm{n}^{\text {th }} \text { land use within the station } \\
& \text { buffer area }
\end{aligned}
$$

The values of land-uses mix (or entropy) range from 0 to 1 , with lower land-use mix buffers (i.e., buffers with more homogeneity in land uses) having values closer to 0 and buffers with greater land use mix having values closer to 1 . As shown in the above equation, land uses are measured in acres. This presents an important difference relative to Frank's measurement of land uses in terms of square footage of the built area. Measurement of the built-area square footage is a more accurate reflection of the built environment in that it captures the height of land development. Measuring land uses in terms of acreage is limited to only capturing the footprint of land development. Limited data availability associated with the San Diego study area required usage of the weaker land-use measure.

Street network pattern is an essential characteristic of the built environment. It is generally thought that more highly-connected street networks are more conducive to walking because the pedestrian has a greater number of route choices between any two trip ends. A denser street network of small streets, as opposed to a sparse network of large streets, generally creates an environment more easily negotiated by the pedestrian. A more highly-connected and denser street 
network should provide a built environment with shorter street blocks, slower vehicular travel speeds, and shorter distances between land uses, all of which are hypothesized to increase the appeal of walking. In this research, street network pattern is measured in terms of the number of intersections per station area buffer acre (Frank et al. 2006, 2005 and 2003).

The measures described above were combined into a composite variable developed by Frank and referred to as a "walkability index." The walkability index relies upon Z-scores, which transforms each of the input variables to a standard deviation. The index therefore allows for the consideration of components using differing units of analysis.

Walkability Index $=2 x[Z($ Land Use Mix $)+Z($ Residential Density $)+$

$$
\text { Z(Retail FAR) + Z(Intersection Density)] }
$$

\section{Socio-Economic Data}

Median household income, the number of households without a vehicle, gender (\% female), ethnicity (\% Hispanic and \% White), and age (\% under 14 years and \% over 75 years) were assessed for the station buffer area. Previous literature shows that low-income households and households without access to vehicles tend to rely upon transit more heavily than higher-income households and households owning one or more vehicles. Previous research also documents how age, ethnicity, and gender impact transit use.

\section{Data Analysis}

Multiple regression equations were estimated in SPSSv13 to test the relative significance of built-environment and socio-economic independent variables in predicting bus transit ridership. Frequency distributions revealed the dependent variable (daily bus transit ridership) follows a nonlinear distribution and is therefore transformed and modeled in its loglinear form. Table 3 presents descriptive statistics for the dependent and independent variables. 
Table 3. Descriptive Statistics $(\mathbf{N}=3,582)$

\begin{tabular}{|c|c|c|c|c|c|}
\hline \multicolumn{2}{|c|}{ Variables } & \multirow{2}{*}{$\begin{array}{c}\text { Units } \\
\text { Daily passengers }\end{array}$} & \multirow{2}{*}{$\begin{array}{c}\text { Range } \\
0-4,509\end{array}$} & \multirow{2}{*}{$\begin{array}{c}\text { Mean } \\
71.2\end{array}$} & \multirow{2}{*}{$\begin{array}{c}\text { Std Dev } \\
189.0\end{array}$} \\
\hline $\begin{array}{l}\text { Bus Ridership } \\
\text { (dependent variable) }\end{array}$ & Boardings/Alightings & & & & \\
\hline $\begin{array}{l}\text { Transit Level of Service } \\
\text { (indepependent } \\
\text { variable) }\end{array}$ & Level of Service & Index & $0.013-0.69$ & 0.06 & 0.05 \\
\hline \multirow{6}{*}{$\begin{array}{l}\text { Socio-Economic } \\
\text { (independent } \\
\text { variables) }\end{array}$} & Income & $\begin{array}{l}\text { Annual median } \\
\text { household income }\end{array}$ & $\$ 8,393-\$ 137,500$ & $\$ 43,505$ & $\$ 17,698$ \\
\hline & $\begin{array}{l}\text { No-vehicle } \\
\text { households }\end{array}$ & Households & $0-1,530$ & 221 & 286 \\
\hline & Percent Female & Percent & $2.7 \%-59.4 \%$ & $49.0 \%$ & $5.7 \%$ \\
\hline & Percent Hispanic & Percent & $4.0 \%-100 \%$ & $29.1 \%$ & $23.8 \%$ \\
\hline & Percent White & Percent & $2.1 \%-92.3 \%$ & $49.4 \%$ & $28.0 \%$ \\
\hline & Percent Youth & Percent & $0-83.8 \%$ & $32.0 \%$ & $15.2 \%$ \\
\hline \multirow{12}{*}{$\begin{array}{l}\text { Built Environment } \\
\text { (indepependent } \\
\text { variables) }\end{array}$} & Station area buffer & Acres & $17.1-663.3$ & 274.7 & 63.9 \\
\hline & Commercial & $\begin{array}{l}\text { Percent of total } \\
\text { buffer area }\end{array}$ & $0 \%-84 \%$ & 9.2 & 9.5 \\
\hline & Industrial & $\begin{array}{l}\text { Percent of total } \\
\text { buffer area }\end{array}$ & $0 \%-81 \%$ & 4.2 & 11.1 \\
\hline & Institutional & $\begin{array}{l}\text { Percent of total } \\
\text { buffer area }\end{array}$ & $0 \%-94 \%$ & 6.0 & 7.7 \\
\hline & Office & $\begin{array}{l}\text { Percent of total } \\
\text { buffer area }\end{array}$ & $0 \%-42 \%$ & 1.9 & 4.2 \\
\hline & Park and Recreation & $\begin{array}{l}\text { Percent of total } \\
\text { buffer area }\end{array}$ & $0 \%-71 \%$ & 6.8 & 8.3 \\
\hline & Residential & $\begin{array}{l}\text { Percent of total } \\
\text { buffer area }\end{array}$ & $0 \%-79 \%$ & 39.8 & 19.9 \\
\hline & Vacant & $\begin{array}{l}\text { Percent of total } \\
\text { buffer area }\end{array}$ & $0 \%-64 \%$ & 2.7 & 5.8 \\
\hline & Retail FAR & Ratio & $0-2.3$ & 0.44 & 0.33 \\
\hline & Residential density & $\begin{array}{l}\text { Number of units / } \\
\text { residential acre }\end{array}$ & $0-146$ & 16.4 & 19.8 \\
\hline & Land use mix & Index & $0.1-0.92$ & 0.48 & 0.12 \\
\hline & Walkability & Index & $-11.9-23.3$ & -0.08 & 4.08 \\
\hline
\end{tabular}

Tables 4 and 5 present the results of two regression models. Model 1 predicts bus ridership using socio-economic characteristics and transit level of service within the station buffer area as independent variables, while Model 2 predicts bus ridership based upon socio-economic characteristics, transit level of service, and the "walkability" of the built environment surrounding the station area. 
Table 4. Regression Model Predicting Bus Ridership with Transit Level of Service and Socio-Economic Characteristics of the Station Area (Model 1)

\begin{tabular}{|c|c|c|c|c|}
\hline \multicolumn{2}{|c|}{ Variables } & $\begin{array}{c}\text { Standardized } \\
\text { Coefficient }\end{array}$ & t-stat & Significance \\
\hline \multicolumn{5}{|l|}{ Constant } \\
\hline $\begin{array}{l}\text { Transit Level of } \\
\text { Service }\end{array}$ & Level of Service & 0.372 & 25.021 & .000 \\
\hline \multirow{6}{*}{ Socio-Economic } & Income & -0.128 & -6.626 & .000 \\
\hline & No-vehicle households & 0.244 & 14.119 & .000 \\
\hline & Percent Female & 0.110 & 6.415 & .000 \\
\hline & Percent Hispanic & 0.043 & 1.504 & .133 \\
\hline & Percent White & -0.113 & -3.439 & .001 \\
\hline & Percent Youth & -0.111 & -3.916 & .000 \\
\hline \multirow{4}{*}{$\begin{array}{l}\text { Summary } \\
\text { Statistics }\end{array}$} & $\mathrm{N}$ & \multicolumn{3}{|c|}{3,582} \\
\hline & Adjusted $\mathrm{R}^{2}$ & \multicolumn{3}{|c|}{.328} \\
\hline & $\mathrm{F}$ & \multicolumn{3}{|c|}{250.364} \\
\hline & $b$ & \multicolumn{3}{|c|}{.000} \\
\hline
\end{tabular}

Table 5. Regression Model Predicting Bus Ridership with Walkability, Transit Level of Service, and Socio-Economic Characteristics of the Station Area (Model 2)

\begin{tabular}{|c|c|c|c|c|}
\hline \multicolumn{2}{|c|}{ Variables } & \multirow[t]{2}{*}{ Coefficient } & \multirow[t]{2}{*}{ t-stat } & \multirow[t]{2}{*}{ Significance } \\
\hline Constant & & & & \\
\hline $\begin{array}{l}\text { Transit Level of } \\
\text { Service }\end{array}$ & $\begin{array}{l}\text { Level of } \\
\text { Service }\end{array}$ & 0.367 & 24.619 & .000 \\
\hline \multirow{6}{*}{ SocioEeconomic } & Income & -0.118 & -6.059 & .000 \\
\hline & $\begin{array}{l}\text { No-vehicle } \\
\text { households }\end{array}$ & 0.215 & 11.499 & .000 \\
\hline & $\begin{array}{l}\text { Percent } \\
\text { Female }\end{array}$ & 0.115 & 6.721 & .000 \\
\hline & $\begin{array}{l}\text { Percent } \\
\text { Hispanic }\end{array}$ & 0.025 & 0.851 & .395 \\
\hline & $\begin{array}{l}\text { Percent } \\
\text { White }\end{array}$ & -0.132 & -3.977 & .000 \\
\hline & $\begin{array}{l}\text { Percent } \\
\text { Youth }\end{array}$ & -0.090 & -3.148 & .002 \\
\hline $\begin{array}{l}\text { Built } \\
\text { Environment }\end{array}$ & Walkability & 0.072 & 4.010 & .000 \\
\hline \multirow{4}{*}{$\begin{array}{l}\text { Summary } \\
\text { Statistics }\end{array}$} & $\mathrm{N}$ & 3,582 & & \\
\hline & Adjusted $\mathrm{R}^{2}$ & .330 & & \\
\hline & $\mathrm{F}$ & 222.002 & & \\
\hline & $p$ & .000 & & \\
\hline
\end{tabular}


Model 1 depicts statistically-significant and expected relationships between bus ridership and the socio-economic characteristics and transit level of service. Higher median household incomes, higher percent White, and higher percent youth in the station area are significantly associated with lower levels of transit ridership at any particular bus stop. Higher numbers of no-vehicle households, percent Hispanics, and percent female within the vicinity of a transit stop are significantly associated with higher levels of bus ridership. The transit level-ofservice measure was the most significant predictor of bus ridership and showed the expected positive relationship. The adjusted R-squared shows that roughly 32.8 percent of the variation in bus ridership is explained by socio-economic characteristics and transit level of service.

Model 2 incorporates the same socio-economic variables along with the walkability measure to determine the extent to which the built environment improves the explanatory power of the regression equation. As with Model 1, Model 2 depicts statistically-significant and expected relationships between bus ridership and socio-economic characteristics. Model 2 also shows a significant and expected relationship between bus ridership and walkability. Higher levels of walkability in the station area are associated with higher bus ridership at any particular station. The adjusted R-squared shows that roughly 33.0 percent of the variation in bus ridership is explained by the socio-economic factors, transit level of service, and walkability characteristics of the transit station area.

\section{Discussion}

The current study offers important new evidence of the utility of a walkability index for predicting transit ridership. Previously published applications of the walkability index demonstrate associations with vehicle miles traveled and air pollution, levels of moderate physical activity, and body mass index. Previous research shows the walkability index explains roughly 8 percent of the variation in walking, and 2 percent and 4 percent of the variation in VMT and levels of moderate physical activity, respectively (Frank et al. 2006). The current research shows that while significant, the walkabilty index explained approximately 0.5 percent of the variation in bus transit ridership. Some of this discrepancy may appear due to weaknesses in the San Diego built-environment data, specifically the availability of land-use data in acres and not square feet. This is consistent with recent research demonstrating that the amount of commercial floor space, acting as a proxy for 
numbers of employees and overall "trip-end densities" within residential areas was the strongest predictor of transit use (King County 2006).

Overall, however, the walkability of the built environment is significant with the expected relationship to bus transit ridership. These findings, therefore, contribute to a growing body of evidence showing there are significant relationships between the environments in which we live and our behaviors. This research also serves to replicate and validate the application of the walkability index as a measure of the built environment. Finally, this work further supports an approach to transit planning where transit stops are centrally-located within dense, mixed-use activity centers, rather than skirting the periphery of these activity centers, which has historically happened in order to placate transit-resistant neighbors (Ryan 2005).

\section{Policy Implications}

There is mounting evidence that the quality of the built environment influences key behaviors of concern to federal, state, and local policy-makers covering a range of public health and welfare concerns, including air pollution, traffic congestion, obesity, physical activity attainment, crime, and civic engagement. The analyses presented in this paper are particularly meaningful to local and regional policy-makers striving to change the built environment so that it supports walking and transit use. Local and regional transportation and land-use planners need evidence showing why land use matters as they attempt to advocate for the adoption of long-range land use plans promoting smart growth planning principles. In terms of transportation planning, this research provides support to regional transportation planning agencies for the continued use of transportation funding as an incentive for local governments to pursue smart growth land use plans and implementation tools.

Another important policy implication of this research is that it supports the use of the walkability index as a land-development standard or performance measure, which could be incorporated into the local land-development process. The walkability index, for example, could be used to assess the degree to which new development proposals enhance or weaken the pedestrian environment of the project neighborhood. The walkability index could also be used to assess how well future land use and circulation element alternatives achieve walkability goals. Instead of relying predominately upon the regional transportation model and forecast roadway deficiencies as the primary measure of acceptable land use/circulation element coordination, the walkability index might offer a more holistic, yet still quantitative, measure of the likely success of future land-use and transportation 
systems. Finally, the walkability index presented in this paper may be useful as a programming tool for transit agencies to use as they consider where and how to expand transit service. With the support of metropolitan planning organizations, it may be possible in certain locations to reward local governments with increased transit service based on their level of commitment to increasing walkability along existing and proposed transit alignments.

\section{Future Research}

This research points to needed improvements in the measurement of the built environment and for improved quality and access to parcel level land use data. Poor availability of building square footage data for San Diego may relate to Proposition 13 and the reduced property assessments requirements in California. Researchers conducting assessments of Californian metropolitan areas will need to be creative in their efforts to overcome this problem, perhaps using orthophotography to measure building height, width and length and thereby computing building square footage. One key improvement in measuring community walkability might be to incorporate a sense of the three-dimensionality of the street environment. New urbanists make strong reference to the importance of the minimum 1:3 building height-to-street width ratio, for example. Operationalizing this concept in GIS would most likely enhance the degree to which the pedestrian experience is captured by objective GIS measures.

\section{References}

Bento, A., M. Cropper, A. Mobarak, and K. Vinha. 2005. The effects of urban spatial structure on travel demand in the United States. The Review of Economics and Statistics 87(3): 466-478.

Boarnet, M., K. Day, C, Anderson, T. McMillan, and M. Alfonzo. 2005. California's safe routes to school program: Impacts on walking, bicycling, and pedestrian safety. Journal of the American Planning Association 71(3): 301-317.

Calthorpe, P. 1993. The next American metropolis: Ecology, community, and the American dream. New York: Princeton Architectural Press.

Cervero, R. and K. Kockelman. 1997. Travel demand and the three D's: Density, diversity and design. Transportation Research D 2: 199-219. 
Demerath, L. and D. Levinger. 2003. The social qualities of being on foot: $A$ theorectical analysis of pedestrian activity, community, and culture. City and Community 2(3): 217-237.

Duany, A., E. Plater-Zyberk, and J. Speck, J. 2000. Suburban nation: The rise of sprawl and the decline of the American Dream. New York: North Point Press.

Ewing, R., R. Pendall, and D. Chen. 2003. Measuring sprawl and its transportation impacts. Transportation Research Record 1832: 175-183.

Frank, L., P. Engelke, and T. Schmid. 2003. Health and community design: The impact of the built environment on physical activity. Washington, DC: Island Press.

Frank, L., M. Andresen, and T, Schmid. 2004. Obesity relationships with community design, physical activity, and time spent in cars. American Journal of Preventive Medicine 27( 2).

Frank, L., T. Schmid, J. Sallis, J. Chapman, and B. Saelens. 2005. Linking objectively measured physical activity with objectively measured urban form. American Journal of Preventative Medicine 28(2S2): 117-125.

Frank, L., J. Sallis, T. Conway, J. Chapman, B. Saelens, and W. Bachman. 2006. Multiple pathways from land use to health: Walkability associations with active transportation, body mass index, and air quality. Journal of the American Planning Association 71(1): 75-87.

Jacobs, J. 1961. The death and life of great American cities. New York, New York: Vintage Books.

King, A. , D. Stokols, E. Talen, G. Brassington, and R. Killingsworth. 2002. Theoretical approaches to the promotion of physical activity: Forging a transdisciplinary paradigm. American Journal of Preventative Medicine 23(2S): 15-25.

King County Office of Regional Transportation Planning. 2005. A study of land use, transportation, air quality and health in King County, WA. Prepared by Lawrence Frank and Company, Inc., J. Sallis, B. Saelens, McCann Consulting, GeoStats LLC, and K. Washbrook.

Krizek, Kevin J. 2003. Residential relocation and changes in urban travel: Does neighborhood-scale urban form matter? Journal of the American Planning Association 69(3): 265-281. 
Lavizzo-Mourey, R., and J. McGinnis. 2003. Making the case for active living communities. American Journal of Public Health 93: 1386-1388.

Leyden, K. 2003. Social capital and the built environment: The importance of walkable neighborhoods. American Journal of Public Health 93( 9): 1546-1551.

Loukaitou-Sideras, A. 1999. Hot spots of bus crime: the importance of environmental attributes. Journal of the American Planning Association 65(4): 395-411.

Newman, O. 1972. Defensible space: Crime prevention through urban design. New York, New York: MacMillan.

Newman, P., and J. Kenworthy. 1989. Gasoline consumption and cities: A comparison of U.S. cities with a global survey. Journal of the American Planning Association 55(1): 24-37.

Putnam, R. 2000. Bowling alone: The collapse and revival of American community. New York, New York: Simon and Schuster.

Saelens, B., J. Sallis, and L. Frank. 2003. Environmental correlates of walking and cycling: How findings from transportation, urban design, and city planning literature can inform physical activity research. Annals of Behavioral Medicine 24: 3.

Sallis, J., L. Frank, B. Saelens, and M. Kraft. 2004. Active transportation and physical activity: Opportunities for collaboration on transportation and public health research. Transportation Research Part A: Policy and Practice 38: 249-268.

Song, Y., and D. Rodriguez. 2005. The measurement of the level of mixed land uses: A synthetic approach. Environment and Planning $B$, submitted.

Spellerberg, I., and P. Fedor. 2003. A tribute to Claude Shannon (1916-2001) and a plea for more rigorous use of species richness, species diversity, and the "Shannon-Wiener" index. Global Ecology and Biogeography 12: 177-179.

Transportation Research Board and Institute of Medicine. 2005. Does the built environment influence physical activity? Examining the evidence. Special Report 282. Washington, D.C.: Transportation Research Board.

Ryan, S. 2005. The value of access to highways and light rail transit: Evidence for industrial and office firms. Urban Studies 42(4): 751-764. 
Zhang, M. 2004. The role of land use in travel mode choice. Journal of the American Planning Association 70(3): 344-360.

\section{About the Authors}

SHERRY RYAN (sryan@mail.sdsu.edu) is an associate professor of City Planning in the School of Public Affairs at San Diego State University. She teaches courses in land use planning, transportation planning, and geographic information systems, and conducts research on urban transportation-land use interactions.

LAWRENCE F. FRANK (Idfrank@interchange.ubc.ca) is the J. Armand Bombardier Chair in Sustainable Transportation in the School of Community and Regional Planning at the University of British Columbia where he teaches land use and transportation interaction and health and community design. 